\title{
The Analysis of Mining Companies' Corporate Sustainability Assessment Methods (International and Russian Approaches)
}

\author{
Oksana Marinina ${ }^{1,{ }^{*}, \text { Tatiana Ponomarenko }}{ }^{1}$, Marina Nevskaya ${ }^{1}$, and Punsalmaa Ochirbat $^{2}$ \\ ${ }^{1}$ Saint Petersburg Mining University, Saint Petersburg, Russia \\ ${ }^{2}$ Mongolian State University of Sciences and technology, Mongolia
}

\begin{abstract}
The study presents the classification and analysis of corporate sustainability assessment methods. We identified the strengths and weaknesses of the methodological approach to determining the resulting indicators and the possibility of applying these methods for administrative objectives. The results of the study prove that modern international and Russian methods for assessing corporate sustainability can be classified according to the goal, the choice of key indicators, the way of collecting information and industry specifics
\end{abstract}

\section{Introduction}

By various estimates, the world's practice introduces about 150-200 ratings and indices of corporate sustainability, which differ both in terms of their thematic scope and in terms of assessment criteria and indicator composition.

An analysis of scientific publications and official materials of organizations that provide methodological guidance for corporate sustainability (CS) and related areas (for example, corporate social responsibility) showed that the methods differ in [1]:

- the number, composition and weights of assessment indicators;

- the degree of aggregating indicators;

- the methods of calculating the resulting value;

- the choice of information sources for calculating indicators.

The main goal of the work is to analyze corporate sustainability assessment methods for the purpose of their further application in mining companies. By means of content analysis, the study identifies the strengths and weaknesses of the methodological approach to determining the resulting indicators and the possibility of applying the methods for managing mining companies' CS.

The main objectives of the study are:

- To identify the research area by collecting data on the most common methodologies used by industrial companies or rating agencies.

- To evaluate the selected methodologies according to their goals, objectives, the sequence of collecting information and disclosure of the approach to assessment, a chech-

*Corresponding author: Marinina_OA@pers.spmi.ru 
out system, verification and the possibility of including the specifics of mining companies in the resulting indicators.

\section{Methodology}

The methodology of the research is based on the principles of an integrated approach to the assessment and analysis of Russian and international methods for assessing CS. It represents the sequence of collecting, processing and verifying the results (Fig. 1).

\begin{tabular}{|c|c|c|}
\hline $\begin{array}{l}\text { Data } \\
\text { Collection }\end{array}$ & Data Analysis & Credibility of Research \\
\hline $\begin{array}{l}\text { A set of Russian } \\
\text { and } \\
\text { international CS } \\
\text { methods }\end{array}$ & $\begin{array}{c}\checkmark \quad \text { Analysis of } \\
\text { information on the } \\
\text { application of the } \\
\text { methodologies; } \\
\checkmark \quad \text { Selection of the most } \\
\text { significant } \\
\text { methodologies for } \\
\text { assessment and } \\
\text { analysis; } \\
\checkmark \text { Qualitative analysis } \\
\text { of their strengths and } \\
\text { weaknesses }\end{array}$ & $\begin{array}{c}\text { The oppositional method: } \\
\checkmark \quad \text { regulatory documents, } \\
\text { standards in CS; } \\
\checkmark \quad \text { reports of Russian and } \\
\text { foreign agencies } \\
\text { (Bloomberg, RSPP, } \\
\text { etc.); } \\
\checkmark \quad \text { scientific articles on the } \\
\text { acceptance of modern } \\
\text { methods and tools of } \\
\text { analysis and assessment } \\
\text { in the field of CS }\end{array}$ \\
\hline
\end{tabular}

Fig. 1. Research Design

For analysis purposes the following methodologies were selected:

- International methods for assessing CS and social performance

- Methods for assessing SC and social performance with the industry specifics

- Methods and approaches for assessing social performance

- Russian rating methods for assessing CS and social performance

- Individual researchers' methods of assessing companies' performance.

\section{Result and discussion}

By CS assessment methods companies improve their CS results choosing effective ways to achieve them. This requires not only the transparency of the assessment methodology, convenience of comparing and analyzing information and simplified integration of CS indicators into the process of making investment decisions, but also linking the ratings to global requirements, taking into account the industry specifics, identifying CS factors in the formation of value chains and supply chains. Companies use CS ratings to make decisions and internal assessments, to identify trends and to support stakeholder communications.

It should be noted that, despite the controversial nature of the concept of corporate sustainability, a number of documents have been developed that regulate the CS requirements and serve as guidelines. The official methods are universal; therefore, they are applied to all companies without focusing on the industry sector. But methods developed in scientific studies are not officially recognized and are not applied, although they often consider industry specifications and show progress in the scientific understanding of CS [1]. 
Table 1. Classification of CS methods, ratings, indices [2-9]

\begin{tabular}{|c|c|}
\hline $\begin{array}{c}\text { Kinds of } \\
\text { Methodologies }\end{array}$ & Methods \\
\hline $\begin{array}{c}\text { Russian } \\
\text { methodologies } \\
\text { (ratings) for } \\
\text { assessing CS and } \\
\text { social } \\
\text { performance }\end{array}$ & $\begin{array}{c}\text { Basic indicators of RSPP (Methodology of the Russian Union of } \\
\text { Industrialists and Entrepreneurs) } \\
\text { RSPP indices (Interfax-Era methodology) } \\
\text { CCI Social Reporting Standard (Chamber of Commerce and Industry) } \\
\text { Fundamental efficiency ratings (compiled by the environmental and } \\
\text { energy rating agency Interfax-ERA) } \\
\text { Methodology for assessing energy efficiency class from E to A ++ } \\
\text { (RERA) (RUSSIAN ENERGY RATING AGENCY) } \\
\text { Russian Regional Network for Integrated Reporting (RRS) } \\
\text { Employer Attractiveness Rating NRA (National Rating Agency) }\end{array}$ \\
\hline $\begin{array}{c}\text { International } \\
\text { methodologies for } \\
\text { assessing CS and } \\
\text { social } \\
\text { performance }\end{array}$ & $\begin{array}{c}\text { Dow Jones Sustainability Index (методология RobecoSam). } \\
\text { FTSE4GOOD } \\
\text { Global 100 Index methodology. } \\
\text { Global Reporting Initiative (GRI) methodology. } \\
\text { Bloomberg ESG Index methology. } \\
\text { DEA (Data Envelopment Analysis) } \\
\text { KLD (Kinder, Lydenberg, and Domini) } \\
\text { O`Brien. } \\
\text { Econometric Impact Index (economic benefit index) proposed by Smith } \\
\text { Carbon Disclosure Project (CDP) (carbon reporting and performance } \\
\text { leaders: Carbon Disclosure Leadership Index, CDLI; Carbon } \\
\text { Performance Leadership Index, CPLI) }\end{array}$ \\
\hline $\begin{array}{l}\text { Methodologies for } \\
\text { assessing CS and } \\
\text { social } \\
\text { performance with } \\
\text { industry specifics }\end{array}$ & $\begin{array}{l}\text { Oil and Gas Industry Guidance on Voluntary Sustainability Reporting. } \\
\text { IPIECA/API (in the field of oil, gas production) } \\
\text { Rating agency Tomorrow's Value Rating (TVR) (oil, gas) } \\
\text { Equitable Origin has released the EO100 Standard (in the field of oil, } \\
\text { gas) } \\
\text { Rating of openness of oil and gas companies in the field of } \\
\text { environmental responsibility (organized by KREON Group) } \\
\text { Rating of the openness of mining and metallurgical companies in Russia } \\
\text { in the field of environmental responsibility }\end{array}$ \\
\hline $\begin{array}{l}\text { Methodologies } \\
\text { and approaches for } \\
\text { assessing social } \\
\text { performance: }\end{array}$ & $\begin{array}{c}\text { SIA (Social Impact Assessment), } \\
\text { SRA (Social Return Assessment), } \\
\text { SCBA (Social Costs-Benefit Analysis), } \\
\text { SVA (Stakeholder Value Added) } \\
\text { Total Impact Measurement and Management (PWC - developer, } \\
\text { approach to assessing the impact of business on the economy, society } \\
\text { and the environment, as well as the tax contribution of the company) } \\
\text { Coalition for Environmentally Responsible Economies (CERES) } \\
\text { Institute for Social and Ethical Responsibility (ISEA) }\end{array}$ \\
\hline $\begin{array}{l}\text { Social Reporting } \\
\text { Standards }\end{array}$ & $\begin{array}{c}\text { AA1000 KCO Institute of Social and Ethical Accountability } \\
\text { SA8000 Social Accountability International } \\
\text { Social Responsibility Guide ISO } 26000\end{array}$ \\
\hline $\begin{array}{l}\text { Methodologies of } \\
\text { Russian } \\
\text { researchers for } \\
\text { assessing } \\
\text { performance } \\
\text { (more than 100) }\end{array}$ & $\begin{array}{c}\text { Skliar E., Zverkovich I. [10]; Penc I. [11], Saprikina O. [12]; D. A. } \\
\text { Endovitsky, Borzakov [13], Ponomarenko T.V., Marinina O.A. [14] etc. }\end{array}$ \\
\hline
\end{tabular}


CS assessment methods can be classified according to the following criteria [15-19]:

- the effectiveness of CS and ratings of companies in terms of sustainable development;

- target orientation: environmental, social or complex indicators of CS assessment;

- the key indicators or the main index;

- the method of collecting information: statistical methods and surveys;

- the inclusion of industry specification.

Studies on the acceptance of modern methods and tools for CS analysis and assessment, as well as the assessment of statistical data on the quality of ratings and methodologies, are reflected in the study Sustain Ability [20]. CS ratings of RobecoSAM, MSCI, CDP, Sustainalytics are considered the most useful, convenient and of the highest quality according to a survey of North American (35\%), European (39\%), Asian (12\%) and other groups (13\%) of experts in 2018 (Fig . 2.). Despite a significant increase in the number of ratings over the past decade, they remain the leaders. Many companies prefer their assessment and control tools [20].

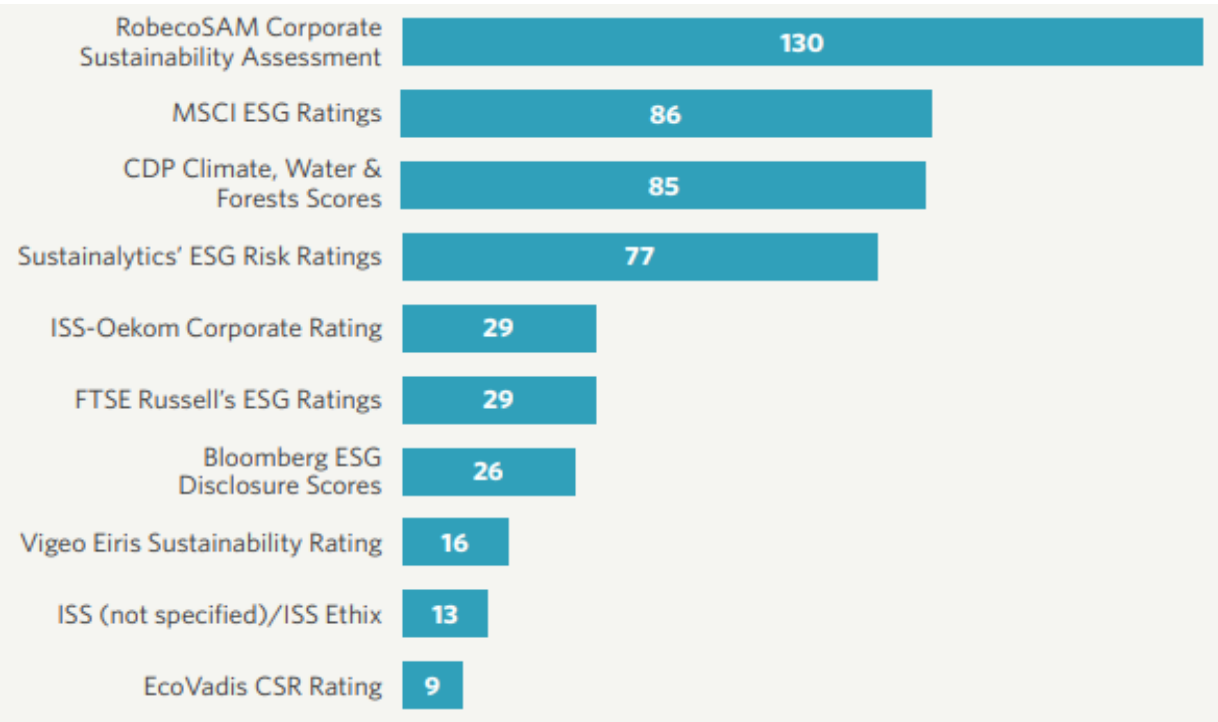

Fig. 2. Rating of CS methodologies by the number of companies using them [20]

The review and analysis of the most well-known methods for assessing CSR and CS showed that, despite their significant number and variety, the methods can be grouped according to the following characteristics.

1. Research area: the area of companies' activities the methods are aimed at. They involve not only methods which are focused on assessing environmental sustainability and the social component of SD in the CSR system and on giving a comprehensive (socioecological) assessment of CSR, but also integrated methods for assessing CSD and analyzing the environmental, social and economic components.

2. Goals: monitoring the situation in the research areas; assessing the social and environmental consequences of project implementation or the activities of companies; constructing company ratings (comparative assessment).

3. Evaluation criteria and indicators and ways of their construction:

- quantitative indicators (for example emissions when assessing environmental impact);

- cost indicators of companies' performance;

- quantitative indicators of companies' areas of activity;

- qualitative indicators for assessing social and environmental effects; 
- aggregate indicators (indices);

- point-rating indicators.

4. Information sources for assessing CS:

- secondary sources (open source);

- primary sources (special surveys of companies);

- primary sources (special surveys of local communities).

5. Express assessment and detailed assessment of CS. Express assessment forms a general idea of the CSR by the company's past activities and non-financial reports and serves as an information base for further analysis, identification of potential risks and making justified decisions. The list of indicators for express assessment reflects the social, economic and environmental significance of the company.

\section{Conclusions}

CS assessment methods vary in the number and composition of indicators, the degree of aggregation of indicators and the ways of calculating the resulting value, weights of indicators, and the degree of the company's progress in CS. Official methodologies are universal and can be applied to all companies without considering their specifics. The methods of individual researchers are rarely used in practice and are not officially recognized, although many of them consider industry specifications.

The characteristic feature of CS assessment methods is that the scheme for choosing criteria, weights and rules for the calculation is not always unknown; the consistency and reliability of the procedures is not confirmed by the disclosure of the approach to collecting relevant information and of the verification system.

Most of the industry methodologies are aimed at solving a narrow problem. For mining companies, these are the methods of environmental or social licensing practices. The rating of environmental responsibility of Russian mining companies is based on the criteria formulated in the environmental requirements for the sector, the sectoral strategy of the World Bank for Development (EBRD), the IRMA Responsible Mining Standard, the GRI Sustainability Reporting Guidelines, etc.

\section{Acknowledgements}

This research was funded by RFBR and MCESSM, grant number № 19-510-44013 \19.

\section{Author Contributions}

Conceptualization, methodology, writing - original draft preparation - O. Marinina; validation, resources, visualization - T. Ponomarenko; formal analysis, investigation $-\mathrm{M}$. Nevskaya, writing - review and editing - P. Ochirbat. All authors have read and agreed to the published version of the manuscript

\section{References}

1. Complex of indices of corporate social responsibility and reporting (2015) https://media.rspp.ru

2. Rate the Raters 2020: Investor Survey and Interview Results (2020) https://sustainability.com

3. C. Wong, A. Brackley, E. Petroy. Expert Views on ESG Ratings February (2019) 
4. ESG factors in investment (2019) https://www.pwc.ru

5. DJSI: Corporate Sustainability Assessment (2012) https://www.spglobal.com

6. Corporate Sustainability Assessment \& Corporate Public Reporting Annelies Poolman (2020) https://www.spglobal.com

7. RepRisk provides ESG intelligence for Dow Jones Sustainability Indices (2014) https://www.reprisk.com

8. Leadership GRI SRS (2013) https://www.globalreporting.org

9. International Integrated Reporting Council ('IIRC') https://integratedreporting.org

10. E. N. Sklyar, Management in Russia and abroad, 2 (2008)

11. I.Sh. Pence, Nedra Communications LTD, 1 (2008)

12. O.A. Saprykina, Transport business in Russia, 5 (2012)

13. D. A. Endovitsky, L. M. Nikitina, D.V. Borzakov, Economic analysis: theory and practice, 8 (2014)

14. T.V. Ponomarenko, O.A. Marinina, Journal of Applied Economic Sciences, 12(6) (2017)

15. A.O. Nedosekin, E.I. Rejshahrit, A.N. Kozlovskiy, Journal of Mining Institute, 237 (2019)

16. A. Tsvetkova, E. Katysheva, SGEM, 19, 573 (2019)

17. V.S. Litvinenko, P.S. Tsvetkov, K.V. Molodtsov, Eurasian Mining (2020)

18. A. Cherepovitsyn, A. Ilinova, Journal of Ecological Engineering, 17, 2 (2016)

19. N. Pashkevich, T. Tarabarinova, Vide, Tehnologija, Resursi - Environment, Technology, Resources, 1 (2017)

20. Rate the Raters 2019 Expert Views on ESG Ratings (2019) https://sustainability.com 